\title{
Effectiveness of Lake Remediation towards Water Quality: Application in Varsity Lake, University of Malaya, Kuala Lumpur
}

(Keberkesanan Pemulihan Tasik Terhadap Kualiti Air: Aplikasi di Tasik Varsiti, Universiti Malaya, Kuala Lumpur)

\author{
NuZAima CHE MOOD*, FARIDAH OTHMAN, NOOR FARAHAIn MUHAMMAD AMIN \& Md IBRAHIM AdHAM
}

\begin{abstract}
Surface water quality monitoring is an important tool for enhancing the water body management system. This study focuses on the water quality of a lake based on rehabilitation work completed in 2014. This lake suffers from eutrophication and water quality degradation due to the increase in pollution rates and water source scarcity. Nine points were selected to represent the water quality status for the study area. Two river tributaries that pass through the University Malaya (UM) campus have been considered due of its potential as a water source for the lake. Field and laboratory analysis were conducted to understand the transport of water quality parameters. The data variations were analyzed using a multivariate statistical method to determine the significant differences between the lake and river. Based on the Malaysian Water Quality Index (WQI) and cluster analysis, the results indicated that the lake and river have different physico-chemical characteristics and the lake water has a better quality than the river. Comparison of the concentration for BOD, TSS, $\mathrm{PO}_{4}^{3-}$ and $\mathrm{NO}_{3}$ - between year 2009 and current study proved that the water quality has improved by $99.8 \%$ proving that the lake remediation is effective.
\end{abstract}

Keywords: Eutrophication; lake water; physico-chemical; remediation; water quality

\section{ABSTRAK}

Pemantauan kualiti permukaan air adalah satu wadah yang penting untuk memperbaiki sistem pengurusan air. Kajian ini memberi tumpuan kepada kualiti air tasik berdasarkan kerja-kerja pemulihan yang dilakukan pada tahun 2014. Tasik ini mengalami eutrofikasi dan penurunan kualiti air kerana peningkatan kadar pencemaran dan kekurangan sumber air. Sembilan lokasi telah dipilih untuk mewakili status kualiti air di dalam kampus Universiti Malaya (UM). Dua buah anak sungai yang melalui kampus UM turut dikaji kerana potensinya sebagai salah satu sumber untuk air tasik. Analisis lapangan dan makmal telah dijalankan untuk memahami pengangkutan parameter kualiti air. Data dianalisis dengan menggunakan kaedah multivariat statistik untuk menentukan perbezaan antara tasik dan sungai. Berdasarkan Indeks Kualiti Air Malaysia (WQI) dan analisis kelompok, keputusan membuktikan bahawa tasik dan sungai mempunyai ciri fiziko-kimia yang berbeza dan air tasik mempunyai kualiti yang lebih baik daripada sungai. Perbandingan bagi BOD, TSS, $\mathrm{PO}_{4}^{3-}$ dan $\mathrm{NO}_{3}^{-}$untuk tahun 2009 dan kajian semasa membuktikan bahawa kualiti air semasa telah meningkat sebanyak 99.8\%. Ini membuktikan bahawa pemulihan tasik adalah berkesan .

Kata kunci: Air tasik; eutrofikasi; fiziko-kimia; kualiti air; pemulihan

\section{INTRODUCTION}

It is crucial to measure the water quality in terms of physical, chemical and biological parameters (Sargaonkar \& Deshpande 2003). There is an abundance of studies worldwide that are related to the physico-chemical characteristics of freshwater (Hu et al. 2008; Lermontov et al. 2009; Rajendran \& Mansiya 2015; Sharma et al. 2015; Sun et al. 2016; Wong \& Hu 2013). In Malaysia, the lake and river water systems are treated as a source of freshwater. The study of the lake and river are important because it is an interactive component of watersheds and the physico-chemical conditions of these ecosystems reflect the land use patterns and physical characteristics of the landscapes in which they are embedded (Morrice et al. 2008; Udo 2007).
Lakes are subjected to additional influences from human activities associated with water regulation, diversion and consumption (Gao et al. 2011). Due to continuous accumulation of pollutants in lakes, primarily from surface run-off and excessive fish feeding, the nutrient level of pond water will gradually increase. As a result, the lake usually suffers from eutrophication and certain amounts of those nutrients will even cause algal blooms (Orderud \& Vogt 2013). Eutrophication of surface water bodies is a worldwide phenomenon (Izmest'eva et al. 2016), creating difficult challenges to all involved in water management and imposing severe environmental costs (Pretty et al. 2003) due to water quality deterioration (Prepas \& Charette 2005; Smith et al. 2006, 1999). A multidisciplinary approach is required to deal with this problem. Numerous approaches 
were implemented to reduce lake water pollution such as preventing or reducing the amount of pollutant loads to the lakes especially the nutrients ( $\mathrm{Hu}$ et al. 2008; Jeppesen et al. 2007, 2005; Köhler et al. 2005; Oglesby \& Edmondson 1966; Skarbøvik \& Bechmann 2010; Welch 1981). Nutrient loads can be reduced by controlling the agricultural activities like pesticides and fertilizers use (Orderud \& Vogt 2013), wetland construction and buffer construction and change in tillage practice (Skarbøvik \& Bechmann 2010). Basic environmental literacy such as interaction between science and stakeholders is also required and this is called as trans-disciplinary research and processes (Orderud \& Vogt 2013).

Varsity Lake in UM campus exhibits typical characteristics of eutrophic lake. This has become worst since 2009 based on the sudden death of fish in the lake on 15 October 2009 (Ashraf et al. 2010). The main water source of the Varsity Lake consists of wastewater flows from faculties and residential colleges. These flows carry overloading pollutants into the lake and it has exceeded the carrying capacity of the lake especially during the dry season. Thus, in August 2014, rehabilitation work started for the lake's preservation. The work aimed to prohibit any untreated wastewater flow into the lake and improving lake water quality. Therefore, the main inlet is fully stopped from flowing into the lake. After the rehabilitation, the lake does not have a well-established inlet as a consistent water source to ensure a good water quality and quantity. Thus, this study includes investigating the suitability of the river system in UM campus for lake water sources by quantifying the water quality levels in the rivers and evaluating the effectiveness of rehabilitation work for the lake to act as recreational use for water sport and body contact. The findings of this paper were compared to a similar study done in eutrophic tropical lake in Ghana due to the identical climate and limnology (Ansa et al. 2011).

\section{MATERIALS AND METHODS}

\section{STUDY AREA}

The University of Malaya is situated on a $3.03 \mathrm{~km}^{2}$ land area in the southwest of Kuala Lumpur, the capital of Malaysia (2015). The current study investigated the water flow through the entire UM campus but focused mainly on the Varsity Lake. Varsity Lake is the biggest lagoon on the UM land with a surface area of $0.0148 \mathrm{~km}^{2}$. It is located at $3^{0} 25^{\prime} 27.52^{\prime \prime} \mathrm{N}, 101^{0} 25^{\prime} 53.89^{\prime \prime} \mathrm{E}$. This lake is a stagnant manmade lake build to meet the recreational and sport activities of the UM. It has become one of the centers of attraction for recreational activities prior to the water quality deterioration in 2009. The water depth ranges from 2.0 to $4.0 \mathrm{~m}$ with a total length of lake of $287 \mathrm{~m}$ and a width range from 10.0 to $80.0 \mathrm{~m}$. During the study, water enters the lake mainly by pumping the water from the nearest river, Sungai Pantai and a small proportion of water enters the lake through surface runoff and direct precipitation. There are two outlets to drain water in case of high water level but in normal water level, Varsity Lake does not have well-established outlets. It was therefore, hypothesized that the lake mostly loses water through subsurface flow and evapotranspiration.

Two river tributaries (Sungai Pantai and Sungai Anak Air Batu) pass through UM campus and they are not connected to the lake. The continuous flow of the rivers makes it sufficient to become a water source for the lake. Sungai Pantai is located at the upstream of Varsity Lake. It receives flow from the outside residential area and flows in a concreted channel of about $1.75 \mathrm{~km}$ long inside the campus and passes by the Varsity Lake. Sungai Anak Air Batu is another tributary, which receives flow from the Damansara area before it merges with Sungai Pantai (Figure 1). It has a total length of $1.93 \mathrm{~km}$.

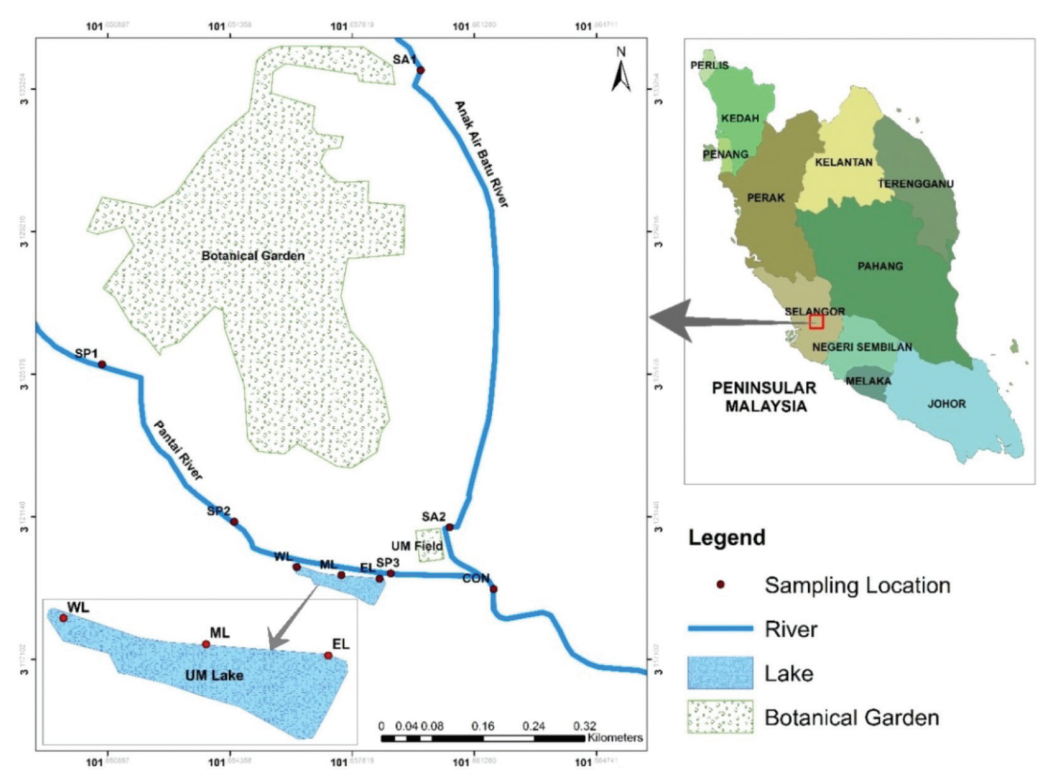

FIGURE 1. University Malaya campus and location of nine sampling points 


\section{SAMPLE COLLECTION AND ANALYSIS}

Field sampling was conducted monthly for a year period from November 2014 to October 2015. Nine sampling stations were selected to represent the variation of water quality status for the study area: Three samples from Varsity Lake, two samples from Sungai Anak Air Batu and four samples from Sungai Pantai. Physical and chemical parameters measured during the sampling were $\mathrm{pH}$, electric conductivity (EC), temperature, dissolved oxygen (DO) and turbidity. After sampling, the samples were kept in a cold room at a temperature of $4^{\circ} \mathrm{C}$ to minimize chemical reaction rate in the water (Eaton et al. 2005). Biochemical oxygen demand (BOD), chemical oxygen demand (COD), total suspended solids (TSS) and ammonical-nitrogen $\left(\mathrm{NH}_{3}-\mathrm{N}\right)$ were tested in laboratory by using a standard method for Examination of Water and Wastewater 20th Edition (Eaton et al. 2005). The method used for BOD analysis was Winkler's method, while COD was determined using Open reflux method. The gravimetric process of total suspended solids at $105^{\circ} \mathrm{C}$ was done for TSS analysis and the Kjedahl method for $\mathrm{NH}_{3}-\mathrm{N}$. The nutrient study involving nitrate $\left(\mathrm{NO}_{3}\right)$ and phosphate $\left(\mathrm{PO}_{4}^{3-}\right)$ tested using Spectrophotometer Pharo 100. The data were interpreted by using SigmaPlot and MINITAB 16. Box-plot analysis was applied to illustrate the trend of physical and chemical characteristics by plotting the concentrations against sampling locations. One way analysis of variance (ANOVA) was applied to determine any significant difference between the sampling stations. The spatial variability of water quality in the UM campus was performed using a hierarchical agglomerative cluster under the Ward's method with squared Euclidean distances as a measure of similarity (Otto 1998). For instance, distance object $\mathrm{x}\left(\mathrm{x}_{1}, \mathrm{x}_{2}\right)$ and object $\mathrm{y}\left(\mathrm{y}_{1}, \mathrm{y}_{2}\right)$ is expressed using (1):

$$
\text { Distance }(\mathrm{x}, \mathrm{y})=\sum_{i=1}^{n}\left(x_{1}-y_{1}\right)^{2}
$$

\section{RESULTS AND DISCUSSION}

\section{PHYSICAL-CHEMICAL CHARACTERISTICS OF THE WATER}

The minimum and maximum values of all physicochemical parameters of water samples collected from nine sampling stations are summarized in Table 1. The table gives range, mean and standard deviation of the result of each of the 10 parameters and the results were compared to the values of the National Water Quality Standards (NWQS) for Malaysia (DOE 1994).

The mean water temperature at the study area ranges from 29.4 to $32.4^{\circ} \mathrm{C}$ and $\mathrm{pH}$ from 6.8 to 8.1 . The results were within the range of the standard acceptable levels of the NWQS, 6.5 to 8.5 . In this study, mean DO varies from 3.3 to $8.0 \mathrm{mg} / \mathrm{L}$ and complies with the standard set by the NWQS, of above $3 \mathrm{mg} / \mathrm{L}$. The mean TSS varies from 8 to $18.8 \mathrm{mg} / \mathrm{L}$. Based on the NWQS, the maximum threshold limit of TSS is $50 \mathrm{mg} / \mathrm{L}$ (DOE 1994). The mean BOD in UM campus range from 1.2 to $4.2 \mathrm{mg} / \mathrm{L}$ with limit given of 6 $\mathrm{mg} / \mathrm{L}$ (DOE 1994). COD concentrations were varied between 0 and $384 \mathrm{mg} / \mathrm{L}$ with a mean range from 21.5 to 52.0 $\mathrm{mg} / \mathrm{L}$. All sampling locations have high standard deviation value indicating that $\mathrm{COD}$ is not consistent throughout the sampling period. The NWQS threshold level for COD is $50.0 \mathrm{mg} / \mathrm{L}$ (DOE 1994). The mean $\mathrm{NH}_{3}-\mathrm{N}$ concentrations were between 0.3 and $3.9 \mathrm{mg} / \mathrm{L}$ and the limit for $\mathrm{NH}_{3}-\mathrm{N}$ concentration which supports aquatic life is $0.9 \mathrm{mg} / \mathrm{L}$ (DOE 1994). Nutrient concentration, $\mathrm{NO}_{3}{ }^{-}$and $\mathrm{PO}_{4}{ }^{3-}$ ranges from 1.8 to $2.1 \mathrm{mg} / \mathrm{L}$ and 0.1 to $1.3 \mathrm{mg} / \mathrm{L}$, respectively. The maximum permissible limit set by the NWQS is $7 \mathrm{mg} / \mathrm{L}$ for $\mathrm{NO}_{3}$ - and $0.2 \mathrm{mg} / \mathrm{L}$ for $\mathrm{PO}_{4}^{3-}$

\section{SUITABILITY OF RIVER WATER FOR VARSITY LAKE WATER SOURCE}

The temperature in the lake was found to be higher than the temperature in the rivers as shown in Figure 2(a) and based on one-way variance tests, the water temperature in the lake has differs significantly with both rivers $\left(\mathrm{F}_{2,33}=\right.$ $6.08, p<0.05)$. Water has high heat storage capacity, so low velocity or stagnant water in the lake tends to accumulate higher heat. Also, lake water receives direct sunlight in a stagnant form while trees at the riverbanks overshadow the rivers and water is continuously flowing. This explains the high temperature in the lake.

From this study, $\mathrm{pH}$ in the lake has differs significantly with the rivers $\left(\mathrm{F}_{233}=14.19, p<0.05\right)$ where the lake water has relatively alkali characteristics with mean of 7.9 to 8.1, Figure 2(b). Higher $\mathrm{pH}$ value was reported in Weija Lake with mean range of 6.5 to 8.7 due to the eutrophic condition (Ansa et al. 2011). Najas spp. was introduced into Varsity Lake to reduce the phytoplankton growth rate as applied in Lake Wuli, China (Chen et al. 2009). Introduction of Najas spp. combined with existing eutrophic condition in Varsity Lake has led to rapid photosynthetic activity (Ansa et al. 2011; Chen et al. 2009; Edmondson 1956; Eilers \& Peeters 1988; Tilzer 1983). Studies by Awuah (2006), Czuba et al. (2011) and Gandaseca et al. (2011) has confirmed that $\mathrm{pH}$ value is higher in environment with high photosynthetic activity as carbon dioxide is utilized in the process (Awuah 2006; Czuba et al.2011). For $\mathrm{pH}$ in the river, the value has reached acidic condition from 4 to 5.5 and this shows that it is unsuitable for lake water source because it may affect the alkalinity of the lake water.

A significant difference was observed between DO in the lake and in the river $\left(\mathrm{F}_{2,33}=45.33, p<0.05\right)$ where lowest concentration was recorded in Sungai Anak Air Batu, 0.9 $\mathrm{mg} / \mathrm{L}$ while the highest was in the lake, $12.8 \mathrm{mg} / \mathrm{L}$, Figure 2(c). High DO was also recorded in Weija Lake with range of 3.5 to $10.5 \mathrm{mg} / \mathrm{L}$ (Ansa et al. 2011). This shows that the presence of algae and high photosynthetic rate in eutrophic condition contribute to high DO concentration. In an aquatic system, all living organisms are dependent on oxygen in one form or another to maintain the metabolic process that produces energy for growth and reproduction (Sawyer et al. 2003). Both rivers has lower DO than the lake and thus, make them unsuitable as a water source in the lake. 
There is no significant difference between the mean of TSS in the river and lake $\left(\mathrm{F}_{2,33}=1.5, p>0.05\right)$. However the pattern shows that Sungai Pantai has the highest TSS, $72 \mathrm{mg} / \mathrm{L}$. This was due to the heavy rainfall events during the sampling period, Figure 2(d). Rainfall has increased the rate of surface runoff or soil erosion. Normally soil erosion considers the best source for suspended solids that comes from the surrounding area (Ooshaksaraie et al. 2009). The inconsistency of TSS concentration in the river makes it unsuitable as a water source in the lake.

Varsity Lake shows significant difference in BOD value compared to the river $\left(\mathrm{F}_{2,33}=6.98, p<0.05\right)$. Highest $\mathrm{BOD}$ was recorded in the Sungai Pantai while the lowest was in the lake, Figure 3(a). A study by Ansa et al. (2011) in Weija Lake has shown that low dissolved organic matter in aquatic environment contribute to low BOD. In Varsity Lake, dissolved organic matter in the form of algae and decomposed Najas spp. is removed periodically by UM volunteers. This give an indication that river has higher biological organisms as compared to the lake and is unsuitable to be used as a water source for the lake because it will affect the DO level in the lake. Meanwhile, COD values did not show significant trend, $\left(\mathrm{F}_{2,33}=0.65, p>0.05\right)$ but fluctuated from time to time, Figure 3(b). Generally, lower COD level indicates a low level of pollution (Waziri \& Ogugbuaja 2010).

There is a significant difference between the mean $\mathrm{NH}_{3}-\mathrm{N}$ in the lake and mean $\mathrm{NH}_{3}-\mathrm{N}$ the river $\left(\mathrm{F}_{2,33}=\right.$ $22.08, p<0.05)$ with the highest value was in the Sungai Pantai and minimal concentration in the lake, Figure 3(c). According to Corwin et al. (1999) higher $\mathrm{NH}_{3}-\mathrm{N}$ values can be toxic to fish and it is an indication of the existence of sewage effluents into a water body. The Sungai Pantai collects pollutants along the river before flows into the UM campus. This means that, Sungai Pantai is unsuitable to be a source of water for Varsity Lake.

Nutrient study, involving $\mathrm{PO}_{4}^{3-}$ and $\mathrm{NO}_{3}{ }^{-}$were also conducted. The highest $\mathrm{PO}_{4}^{3-}$ was recorded in the Sungai Pantai, while the lowest was in the lake, Figure 4(a), $\left(\mathrm{F}_{2,33}=2.47, p<0.05\right)$. Meanwhile, there is no significant pattern for $\mathrm{NO}_{3}^{-}$level between the study areas, Figure $4(\mathrm{~b}),\left(\mathrm{F}_{2,33}=0.09, p>0.05\right)$. High concentrations of nutrients are generally due to the pollution associated with eutrophication condition (WHO 2011). In addition, domestic effluents particularly which contain detergents, fertilizer runoff and industrial wastewater are the main reasons of high $\mathrm{PO}_{4}{ }^{3-}$ levels in surface water such as the river and lake (Ceballas \& Schnabel 1998). From the data, it proves that Sungai Pantai receives effluent from one of the type discharges listed above. The discharge derives from a combination of sources both outside and inside the campus. Figure 4(a), shows that Varsity Lake has a small interquartile range indicating that the $\mathrm{PO}_{4}^{3-}$ level in this lake is consistent. However the river has reached $5 \mathrm{mg} / \mathrm{L}$ of $\mathrm{PO}_{4}{ }^{3-}$. The inconsistency proves that the river have different characteristic from time to time and unsuitable to be a water source for the lake.

\section{COMPREHENSIVE WATER QUALITY CLASSIFICATION}

From the field and laboratory analysis, the result of all parameters listed in Table 1 was used for cluster analysis, Figure 5. The result separates the sampling stations into 4 four natural background features. Cluster 1 corresponded to stations SP1 and SP2 which represent Sungai Pantai as it enters into the UM campus, Cluster 2 represents Varsity
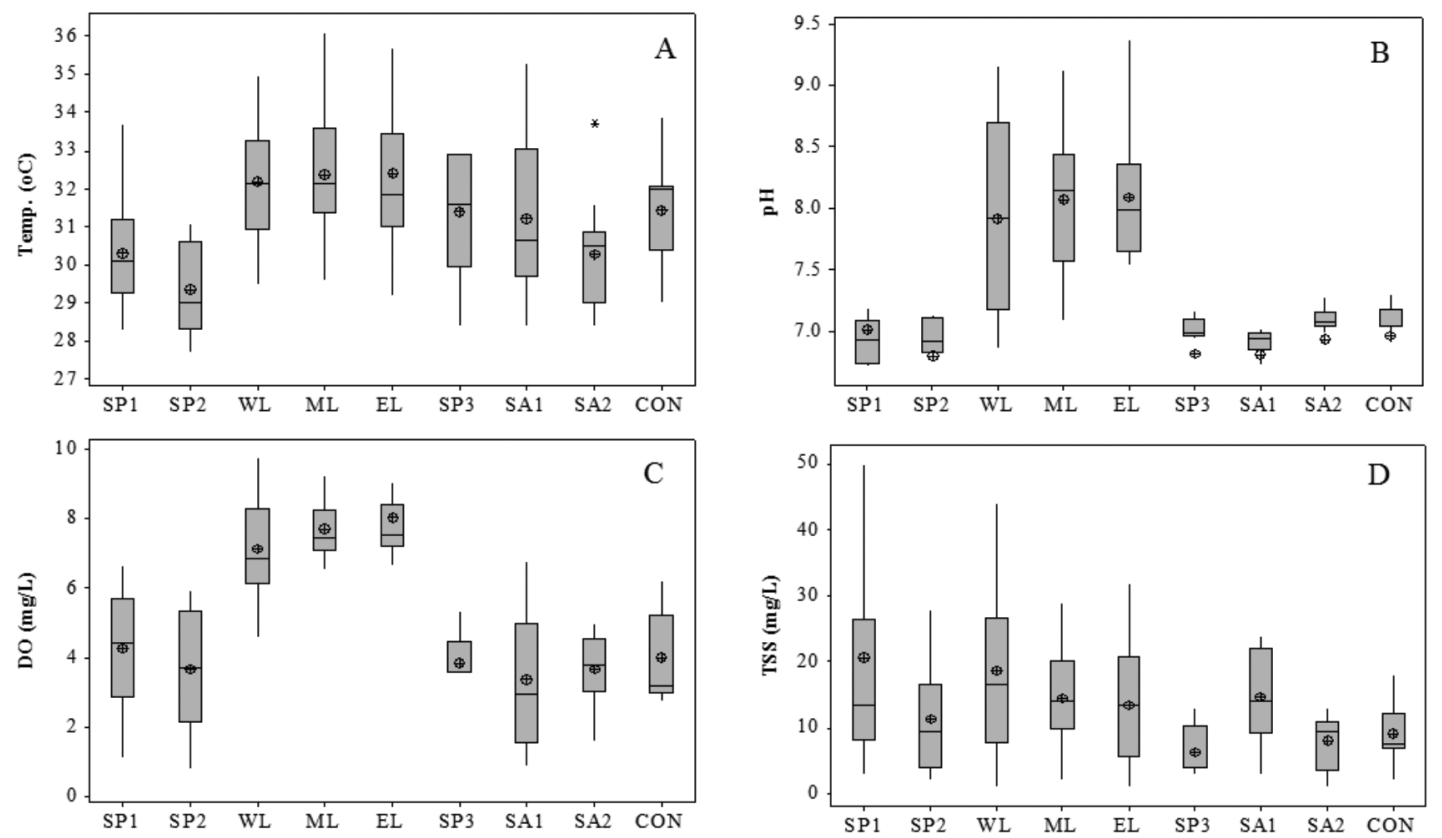

FIGURE 2. Box-plot analyses (A) The temperature against sampling points, (B) pH against sampling points, (C) DO against sampling points and (D) total suspended solids against sampling points 

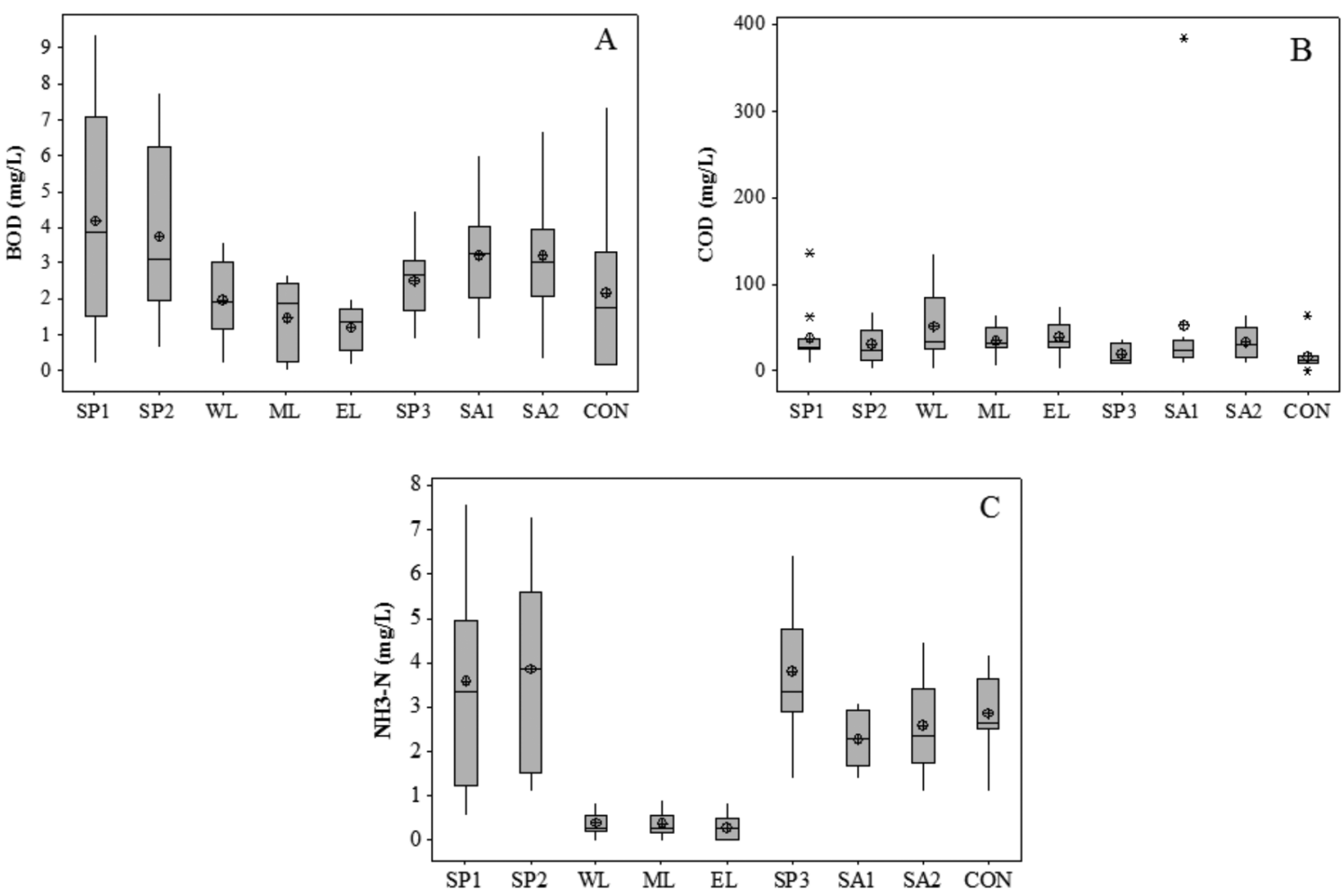

FIGURE 3. Box-plot analyses (A) The BOD against sampling points, (B) COD against sampling points and (C) $\mathrm{NH}_{3}-\mathrm{N}$ against sampling points
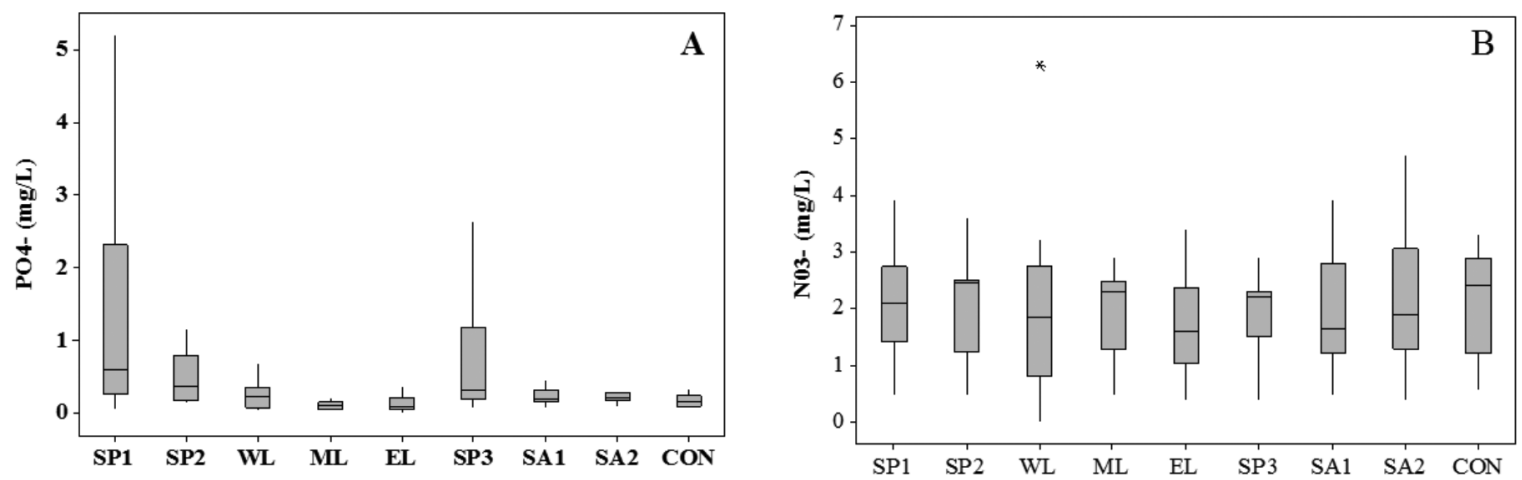

FIGURE 4. Box-plot analyses (A) The $\mathrm{PO}_{4}^{3-}$ against sampling points and (B) $\mathrm{NO}_{3}{ }^{-}$against sampling points

Lake water (WL, ML, EL), Cluster 3 included SP3, CON and SA2, the combination of the Sungai Pantai and Sungai Anak Air Batu and Cluster 4 only contained station SA1 that is located in the upper part of the Sungai Anak Air Batu. This cluster illustrated that lake water lies in different cluster with the river and has a significant difference $\left(\mathrm{F}_{2,33}\right.$ $=28.65, p<0.05)$. Meanwhile, $\mathrm{DO}, \mathrm{BOD}, \mathrm{COD}, \mathrm{TSS}, \mathrm{NH}_{3}-\mathrm{N}$ and $\mathrm{pH}$ were used in the calculation of the WQI based on DOE standard as described by (DOE 1994; Norhayati et al. 1997) to identify the water quality status. WQI is computed based on six Sub-Indexes (SI); in the expression as follows:

$$
\begin{aligned}
\mathrm{WQI}= & 0.22 \mathrm{SIDO}+0.19 \mathrm{SIBOD}+0.16 \mathrm{SICOD} \\
& +0.15 \mathrm{SIAN}+0.16 \mathrm{SISS}+0.12 \mathrm{SIpH}
\end{aligned}
$$

WQI ranges from 0 to 100 and the computed values is classified as Clean for value 81 to 100 , Slightly Polluted for value 60 to 80 and Polluted for value 0 to 59. Based on Table 2, the lake has a mean value range from 82 to 86 indicating that the water is in Class I (Clean). Meanwhile, river water has a mean WQI from 65 to 70 showing that it is in Class II (Slightly Polluted). In overall, this study shows that river water tends to have higher level of contaminants than in lake and similar findings reported by other study (DNR 2010).

\section{EFFECT OF REHABILITATION}

This section discusses the impact of the lake rehabilitation process towards water quality. The comparison is made 


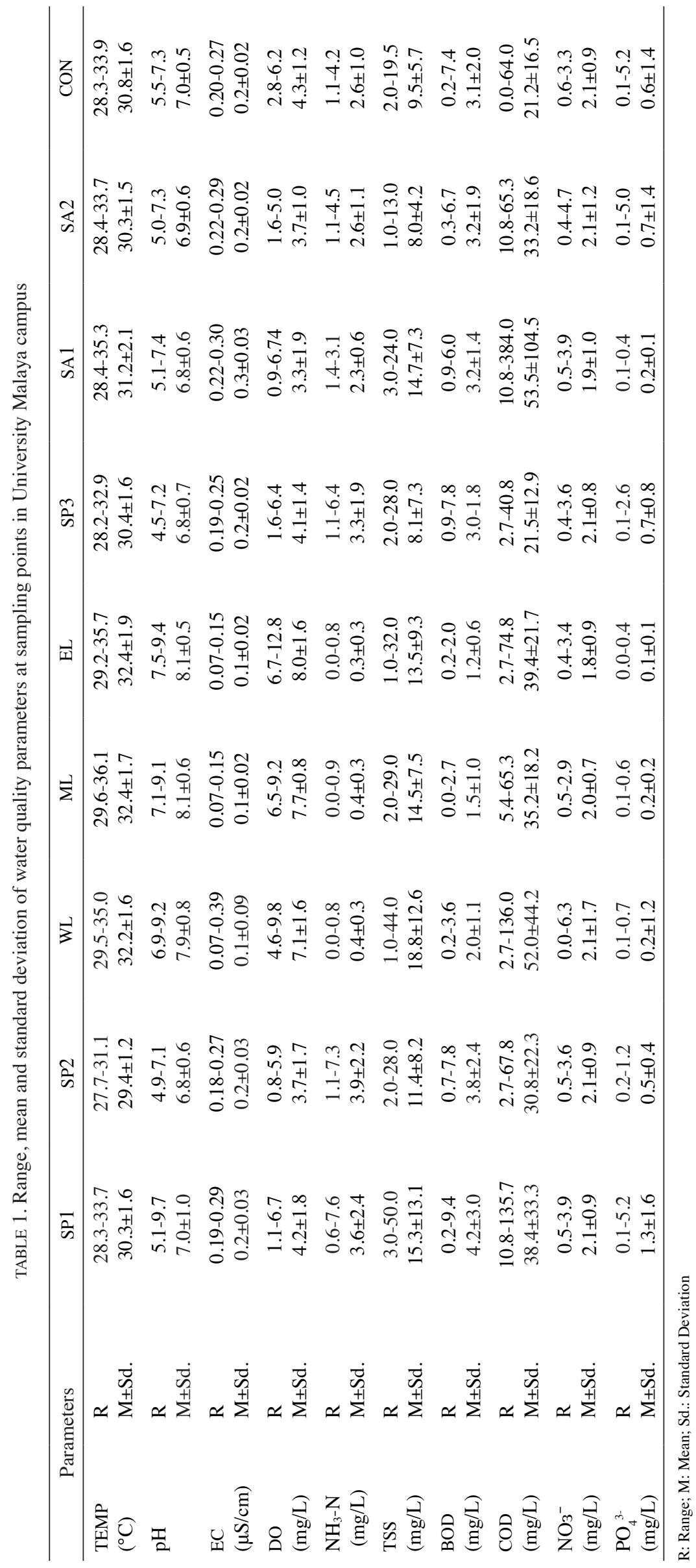




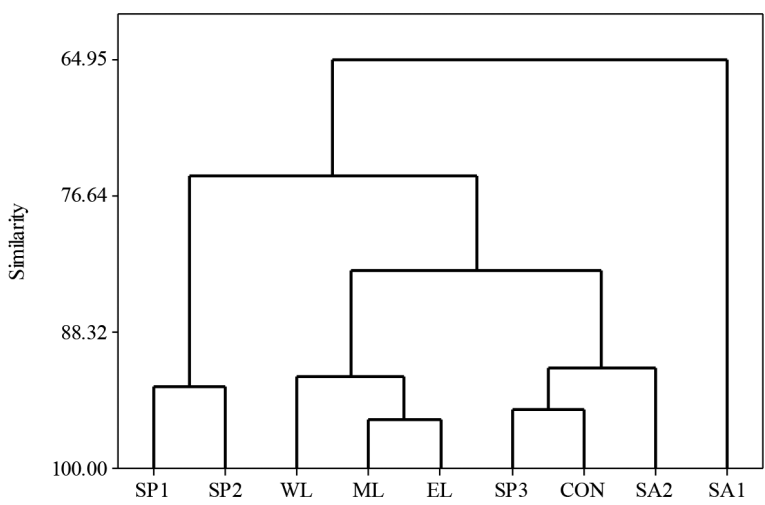

FIGURE 5 . The dendrogram for cluster analysis based on Ward linkage method

TABLE 2. Mean WQI status for surface water in University Malaya campus

\begin{tabular}{clcl}
\hline Station & \multicolumn{1}{c}{ Remarks } & WQI & $\begin{array}{c}\text { INWQS } \\
\text { CLASS }\end{array}$ \\
\hline SP1 & Sungai Pantai & 65 & Class III \\
SP2 & Sungai Pantai & 65 & Class III \\
WL & Varsity Lake & 82 & Class II \\
ML & Varsity Lake & 86 & Class II \\
EL & Varsity Lake & 86 & Class II \\
SP3 & Sungai Pantai & 68 & Class III \\
SA1 & Sungai Anak Air Batu & 66 & Class III \\
SA2 & Sungai Anak Air Batu & 66 & Class III \\
CON & Confluence of rivers & 70 & Class III \\
Mean WQI & & 73 & Class II \\
\hline
\end{tabular}

based on the water quality data before the work began in 2009 and after the work completed in 2014. Comparison of the concentration shows a significant difference (Figure 6). The concentrations for these parameters in 2014 are lower than 2009. This shows that the rehabilitation work has made changes to the lake's water quality. In 2009, the average $\mathrm{NO}_{3}{ }^{-}$concentration was $43.8 \mathrm{mg} / \mathrm{L}$ while in 2014 , the concentration dropped to $1.94 \mathrm{mg} / \mathrm{L}$ (Figure 6(a)). For $\mathrm{PO}_{4}{ }^{3-}$, the concentration in 2009 was $5.4 \mathrm{mg} / \mathrm{L}$ and after rehabilitation work the concentration has reduced to an average value of $0.17 \mathrm{mg} / \mathrm{L}$ (Figure 6(b)). Based on the results, it shows that the control of nutrient loading into Varsity Lake has succeed in bring down the nutrients level to the permissible level as been reported by the study in Lake Maggiore, Italy (Roggiu et al. 1985).

TSS is an important parameter for water quality study because the oxygen will easily dissolve in low suspended solids water. In 2009, average TSS has reached $357.6 \mathrm{mg} / \mathrm{L}$ but after rehabilitation work, the TSS decreased to an average of $15.6 \mathrm{mg} / \mathrm{L}$ (Figure 6(c)). BOD concentration also shows a good indication. The average BOD concentration has declined from 763 to $1.6 \mathrm{mg} / \mathrm{L}$ (Figure 6(d)). The BOD is continuously decreased because of the stoppage of wastewater entering the lake. This phenomenon is common and has been identified in many studies (Edmondson 1995; Rosli et al. 2010; Smith 1998).

In overall, the rehabilitation work that includes; stop of wastewater flow to the lake, soil dredging, harvesting of algae and Najas spp. and installation of soil retainer has reduced the pollutants indicator concentration. This shows that the water quality in the lake is improving from 2009
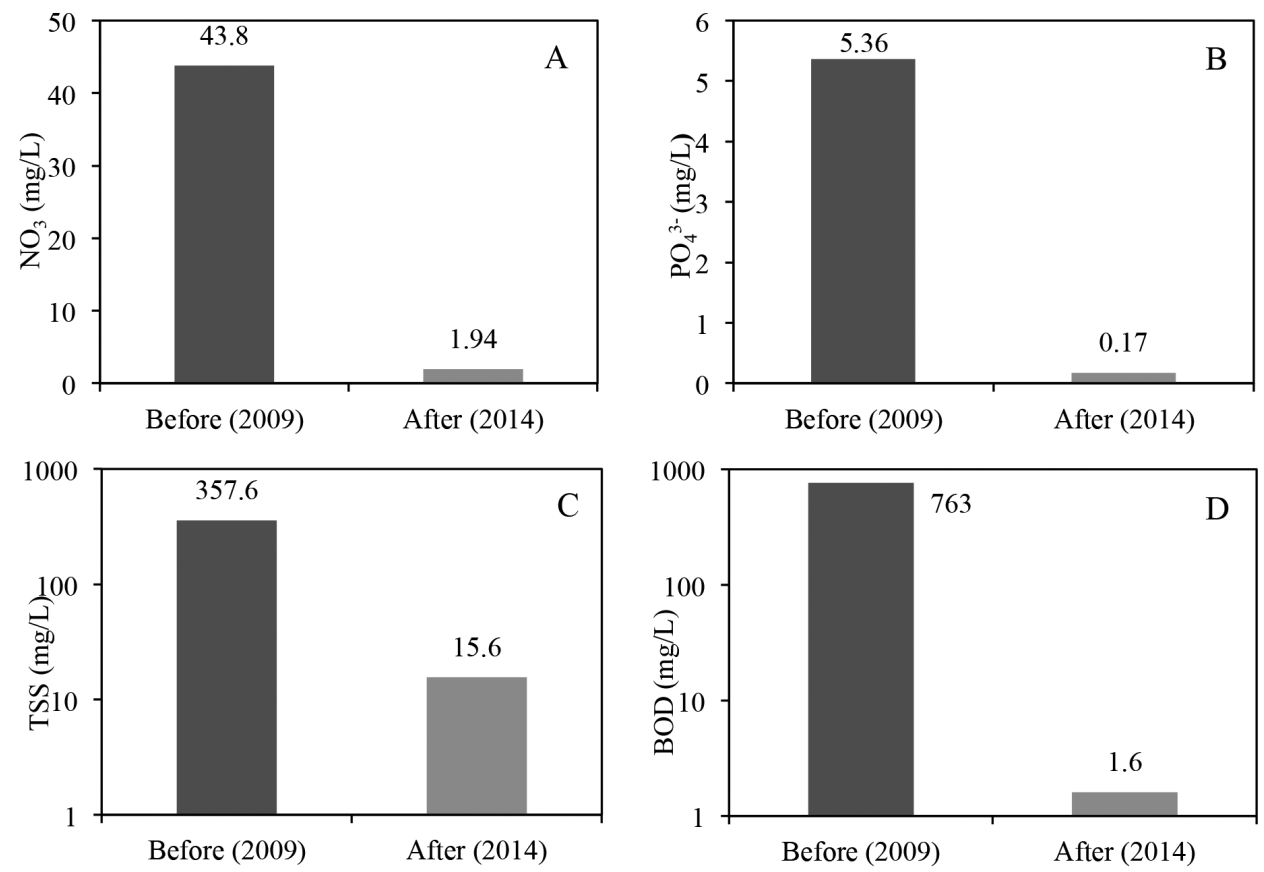

FIGURE 6. The comparison of water quality concentration in Varsity Lake before and after rehabilitation work for (A) $\mathrm{NO}_{3}{ }^{-}$concentration, (B) $\mathrm{PO}_{4}{ }^{3-}$ concentration, (C) TSS concentration and (D) BOD concentration 
to 2014. However each parameter has different amount of reduction and in this study, the reduction is represented using percentage change (Figure 7). From this study, BOD has the highest percentage change of $99.8 \%$, followed by $\mathrm{PO}_{4}^{3-96.8 \%}$ and $\mathrm{NO}_{3}$ - and TSS shares the same percentage change of $95.6 \%$. The stop of wastewater flow to the lake give a major contribution in improving the water quality and similar finding reported by the study in Washington Lake, Seattle USA (Edmondson 1995; Smith 1998). Since all parameters have percentage change nearly $100 \%$, it shows that the rehabilitation work is very effective and totally helps in improving the water quality.

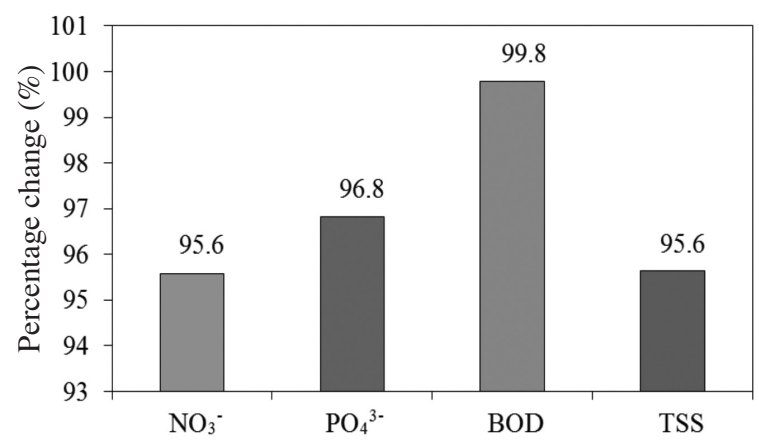

FIGURE 7. The percentage change of water quality concentration before and after the rehabilitation work

\section{CONCLUSION}

The present study demonstrates the water quality in river and lake exhibited large different characteristics physically and chemically. In overall, lake water tended to have a better water quality level (Class II) while the rivers had lower water quality (Class III). These outcomes indicate that the lake water is in a clean state and while the rivers are slightly polluted. Thus, the rivers water is unsuitable for lake water source. This study also gives a better understanding that any pollution source that flows into the rivers will not affect the lake water quality and clearly proved that there is no leakage from the river to the lake. As for the lake water quality, a comparison of the current study with previous study shows that the remediation work towards the lake has improved the water quality by almost $100 \%$ and brings the pollutant indicator concentration to safe level. Thus, lake water is suitable for body contact for recreational purpose. Since the rivers in the campus receive an inflow from outside residences, a master plan is required to improve river water quality by ensuring comprehensive river administration inside the campus and integration between the UM stakeholders and outside local authorities.

\section{ACKNOWLEDGEMENTS}

The authors highly appreciate the financial support from University of Malaya Research Grant (FL001-13SUS, RP017C-15SUS) and the Fundamental Research Grant Scheme (FP016-2014A) from the Ministry of Higher
Education (MOHE), Malaysia. We are most grateful and would like to thank the reviewers for their valuable suggestions, which led to a substantial improvement of the article.

\section{REFERENCES}

UM Fact Sheet 2015. Available from https://www.um.edu.my/ about-um/um-fact-sheet.

Ansa, E.D.O., Lubberding, H.J., Ampofo, J.A. \& Gijzen, H.J. 2011. The role of algae in the removal of Escherichia coli in a tropical eutrophic lake. Ecological Engineering 37(2): 317-324.

Ashraf, M.A., Maah, J.M. \& Ismail Yusoff. 2010. Water quality characterization of varsity lake, University of Malaya, Kuala Lumpur, Malaysia. Journal of Chemistry 7(S1): S245-S254.

Awuah, E. 2006. Pathogen removal mechanisms in macrophyte and algal waste stabilization ponds. PhD Thesis. Wageningen University (Unpublished).

Ceballas, A. \& Schnabel, S. 1998. Hydrological behaviour of small catchment in the Dehesa land use system. Journal of Hydrology 210: 146-160.

Chen, K-N., Bao, C-H. \& Zhou, W-P. 2009. Ecological restoration in eutrophic Lake Wuli: A large enclosure experiment. Ecological Engineering 35(11): 1646-1655.

Corwin, D.L., Loague, K. \& Ellsworth, T.R. 1999. Advanced information technologies for assessing nonpoint source pollution in the vadose zone: Conference overview. Journal of Environmental Quality 28(2): 357-365.

Czuba, J.A., Magirl, C.S., Czuba, C.R., Grossman, E.E., Curran, C.A., Gendaszek, A.S. \& Dinicola, R.S. 2011. Comparability of suspended-sediment concentration and total suspended solids data sediment load from major rivers into puget sound and its adjacent waters. USGS Fact Sheet no. 2011: 083.

Department of Natural Resources. 2010. Difference in Water Quality Impairments: Lakes vs Rivers. Iowa: Iowa Department of Natural Resources, Geological and Water Survey. Water Fact Sheet 2010-9 insert.

DOE. 1994. Classification of Malaysian Rivers. Putrajaya: Department of Environment.

Eaton, A.D., Clesceri, L.S., Rice, E.W., Greenberg, A.E. \& Franson, M.A.H. 2005. APHA: Standard methods for the examination of water and wastewater. Centennial ed., APHA, $A W W A$, WEF, Washington, $D C$.

Edmondson, W.T. 1995. Eutrophication. Encyclopedia of Environmental Biology, vol. 1. New York: Academic Press.

Edmondson, W.T. 1956. The relation of photosynthesis by phytoplankton to light in lakes. Ecology 37(1): 161-174.

Eilers, P.H.C. \& Peeters, J.C.H. 1988. A model for the relationship between light intensity and the rate of photosynthesis in phytoplankton. Ecological Modelling 42(3): 199-215.

Gandaseca, S., Noraini Rosli, Johin Ngayop \& Chandra Iman Arianto. 2011. Status of water quality based on the physicochemical assessment on river water at wildlife sanctuary Sibuti mangrove forest, Miri Sarawak. American Journal of Environmental Sciences 7(3): 269-275.

Gao, H., Bohn, T.J., Podest, E., McDonald, K.C. \& Lettenmaier, D.P. 2011. On the causes of the shrinking of Lake Chad. Environmental Research Letters 6(3): 034021.

Hu, W., Zhai, S., Zhu, Z. \& Han, H. 2008. Impacts of the Yangtze River water transfer on the restoration of Lake Taihu. Ecological Engineering 34(1): 30-49. 
Izmest'eva, L.R., Moore, M.V., Hampton, S.E., Ferwerda, C.J., Gray, D.K., Woo, K.H., Pislegina, H.V., Krashchuk, L.S., Shimaraeva, S.V. \& Silow, E.A. 2016. Lake-wide physical and biological trends associated with warming in Lake Baikal. Journal of Great Lakes Research 42(1): 6-17.

Jeppesen, E., Søndergaard, M., Meerhoff, M., Lauridsen, T.L. \& Jensen, J.P. 2007. Shallow lake restoration by nutrient loading reduction-some recent findings and challenges ahead. Hydrobiologia 584(1): 239-252.

Jeppesen, E., Søndergaard, M., Jensen, J.P., Havens, K.E., Anneville, O., Carvalho, L., Coveney, M.F., Deneke, R., Dokulil, M.T., Foy, B., Gerdeaux, D., Hampton, S.E., Hilt, S., Kangur, K., Köhler, J., Lammens, E.H.H.R., Lauridsen, T.L., Manca, M., Miracle, M.R., Moss, B., Nõges, P., Persson, G., Phillips, G., Portielje, R., Romo, S., Schelske, C.L., Straile, D., Tatrai, I., Willén, E. \& Winder, M. 2005. Lake responses to reduced nutrient loading-an analysis of contemporary long-term data from 35 case studies. Freshwater Biology 50(10): 1747-1771.

Köhler, J., Hilt, S., Adrian, R., Nicklisch, A., Kozerski, H.P. \& Walz, N. 2005. Long-term response of a shallow, moderately flushed lake to reduced external phosphorus and nitrogen loading. Freshwater Biology 50(10): 1639-1650.

Lermontov, A., Yokoyama, L., Lermontov, M. \& Machado, M.A.S. 2009. River quality analysis using fuzzy water quality index: Ribeira do Iguape river watershed, Brazil. Ecological Indicators 9(6): 1188-1197.

Morrice, J.A., Danz, N.P., Regal, R.R., Kelly, J.R., Niemi, G.J., Reavie, E.D., Hollenhorst, T., Axler, R.P., Trebitz, A.S. \& Cotter, A.M. 2008. Human influences on water quality in Great Lakes coastal wetlands. Environmental Management 41(3): 347-357.

Noraini Rosli, Seca Gandaseca, Johan Ismail \& Mohd I. Jailan. 2010. Comparative study of water quality at different peat swamp forest of Batang Igan, Sibu Sarawak. American Journal of Environmental Sciences 6(5): 416-421.

Norhayati, M.T., Goh, S.H., Tong, S.L., Wang, C.W. \& Abdul Halim, S. 1997. Water quality studies for the classification of Sungai Bernam and Sungai Selangor. J. Ensearch 10: 27-36.

Oglesby,R.T.\&Edmondson,W.T. 1966. Control of eutrophication. Journal (Water Pollution Control Federation): 1452-1460.

Ooshaksaraie, L., Noor Ezlin Ahmad Basri, Azuraliza Abu Bakar \& Khairul Nizam Abdul Maulud. 2009. Erosion and sediment control plans to minimize impacts of housing construction activities on water resources in Malaysia. European Journal of Scientific Research 33(3): 461-470.

Orderud, G.I. \& Vogt, R.D. 2013. Trans-disciplinarity required in understanding, predicting and dealing with water eutrophication. International Journal of Sustainable Development \& World Ecology 20(5): 404-415.

Otto, M. 1998. Multivariate methods. In Analytical Chemistry. Weinheim: Wiley-VCH.

Prepas, E.E. \& Charette, T. 2005. Worldwide eutrophication of water bodies: Causes, concerns, controls. In Environmental Geochemistry, edited by Sherwood Lollar, B. Oxford: Elsevier. pp. 311-331.

Pretty, J.N., Mason, C.F., Nedwell, D.B., Hine, R.E., Leaf, S. \& Dils, R. 2003. Environmental costs of freshwater eutrophication in England and Wales. Environmental Science \& Technology 37(2): 201-208.

Rajendran, A. \& Mansiya, C. 2015. Physico-chemical analysis of ground water samples of coastal areas of south Chennai in the post-Tsunami scenario. Ecotoxicology and Environmental Safety 121: 218-222.
Roggiu, D., Mosello, R. \& Pizzolon, L. 1985. Evaluation of nutrient inputs and of the trophic state of Lago Maggiore in recent decades. Paper read at Lake Pollution and Recovery. Proceedings of the International Congress, European Water Pollution Control Association, Associazione Nazionale di Ingegneria Sanitaria, Italy.

Sargaonkar,A. \& Deshpande, V. 2003. Development of an overall index of pollution for surface water based on a general classification scheme in Indian context. Environmental Monitoring and Assessment 89(1): 43-67.

Sawyer, C.N., McCarty, P.L. \& Parkin, G.F. 2003. Chemistry for Environmental and Engineering Science. 5th ed. New York: McGraw Hill Inc.

Sharma, R.C., Singh, N. \& Chauhan, A. 2015. The influence of physico-chemical parameters on phytoplankton distribution in a head water stream of Garhwal Himalayas: A case study. The Egyptian Journal of Aquatic Research 42(1): 11-21.

Skarbøvik,E. \& Bechmann, M. 2010. Some characteristics of the Vansjø-Hobøl (Morsa) catchment. Bioforsk Report 5(128).

Smith, V.H. 1998. Cultural eutrophication of inland, estuarine, and coastal waters. In Successes, Limitations, and Frontiers in Ecosystem Science, edited by Pace, M.L. \& Groffman, P.M. New York: Springer. pp. 7-49.

Smith, V.H., Joye, S.B. \& Howarth, R.W. 2006. Eutrophication of freshwater and marine ecosystems. Limnology and Oceanography 51(1part2): 351-355.

Smith, V.H., Tilman, G.D. \& Nekola, J.C. 1999. Eutrophication: Impacts of excess nutrient inputs on freshwater, marine, and terrestrial ecosystems. Environmental Pollution 100(1): 179-196.

Sun, W., Xia, C., Xu, M., Guo, J. \& Sun, G. 2016. Application of modified water quality indices as indicators to assess the spatial and temporal trends of water quality in the Dongjiang River. Ecological Indicators 66: 306-312.

Tilzer, M.M. 1983. The importance of fractional light absorption by photosynthetic pigments for phytoplankton productivity in Lake Constance. Limnology and Oceanography 28(5): 833-846.

Udo, P.J. 2007. Techniques in Fish Farming (Practice and Management). Calabar-Nigeria: Wusen Publishers.

Waziri, M. \& Ogugbuaja, V.O. 2010. Interrelationships between physicochemical water pollution indicators: A case study of River Yobe-Nigeria. Am. J. Sci. Ind. Res. 1(1): 76-80.

Welch, E.B. 1981. The dilution/flushing technique in lake restoration. Journal of the American Water Resources Association 17(4): 558-564.

WHO. 2011. Guidelines for Drinking-Water Quality. Geneva: World Health Organization.

Wong, H. \& Hu, B.Q. 2013. Application of interval clustering approach to water quality evaluation. Journal of Hydrology 491: $1-12$.

Civil Engineering Department

University of Malaya

50603 Kuala Lumpur, Federal Territory

Malaysia

*Corresponding author; email: enuzaima@siswa.um.edu. my

Received: 8 September 2016

Accepted: 1 February 2017 